\title{
PAK1 Gene
}

National Cancer Institute

\section{Source}

National Cancer Institute. PAK1 Gene. NCI Thesaurus. Code C42592.

This gene is involved in signal transduction and the regulation of both cell mobility and morphology. 